\title{
PENGARUH STRATEGI METAKOGNISI TERHADAP PEMAHAMAN MEMBACA TEKS BERBENTUK DESKRIPTIF PADA MAHASISWA MANAJEMEN INFORMASI KESEHATAN INSTITUT KESEHATAN DELI HUSADA DELITUA
}

\author{
Herawati Br Bukit, Sulastri Br Ginting \\ Institut Kesehatan Deli Husada Deli Tua-Jalan Besar Deli Tua No. 77 \\ e-mail: herawatihill02@gmail.com
}

\begin{abstract}
:
Doing reading comprehension needs active process in doing. The suitable teachinglearning process must achieve the objective of reading comprehension. In fact, reading skill is not easy. Lecturer should use good strategy in teaching about reading comprehension. It also happens for students that they find some hard in doing reading comprehension well. They can't get good value for understanding the text meaning. So, the strategy is very useful to solve the difficulties in reading comprehension. This study is concerned with the reading effect about descriptive text through Metacognition strategy application. This study learns about students reading skills in descriptive text. This research is conducted based on experimental quantitative design which has two randomized subject. The population were Health Information Management students at Deli Husada Deli Tua Health Institute grade I, II and III. The random sample was taken from grade I and III as group of experimental and grade II as the control group. In every group was given pre-test and post-test in same test but the experimental group accepted the treatment of Metacognition strategy in the study. The result of this research showed that there was difference between the mean of the group of experimental and the group of control. The statistic calculation showed that tobserved (4.1) is higher than t-table (1.67). It proves that Metacognition strategy has significantly effect on students' reading comprehension in reading descriptive text.
\end{abstract}

Keywords: Reading Comprehension; Descriptive Text, Metacognitive Strategy

\section{PENDAHULUAN}

Membaca adalah aspek terpenting dalam kehidupan. Setiap bidang di dunia perlu membaca buku untuk mengetahui keahlian. Orang-orang meningkatkan kemampuan otak mereka atau membuktikan keterampilan mereka dengan banyak membaca. Informasi yang terbaru dapat diperoleh dari membaca kata-kata tertulis dari banyak sumber seperti majalah, surat kabar, internet dan sebagainya. Dapat dikatakan bahwa membaca adalah jembatan cahaya (Bukit $\mathrm{H}, 2020$ )

Membaca termasuk satu dari berbagai keterampilan dalam bahasa, selain berbicara, mendengarkan dan menulis. Membaca dan mendengarkan adalah keterampilan reseptif karena keterampilan itu mendapatkan sesuatu selama melakukannya. Sementara, berbicara dan menulis adalah keterampilan produktif karena keterampilan ini menghasilkan sesuatu setelah keterampilan ini dilakukan (Brown, 2001)

Meskipun membaca sangat penting, ternyata keinginan membaca bagi masyarakat Indonesia khususnya peserta didik sangatlah rendah. Menurut Warta Kota (2015: 5) bacaan dalam bahasa Indonesia sangat rendah. Itu dibuktikan oleh UNESCO yang menyatakan bahwa masyarakat Indonesia hanya membaca 7 buku dalam setahun. Ini sangat mempengaruhi rendahnya pemahaman membaca. Selain itu, berdasarkan survey, UNESCO mengindeks bahwa yang suka membaca sangat rendah, 
hanya 0,001. Ini membuktikan dari 1000 masyarakat hanya 1 yang suka membaca (Oke Zone.com, 2015 )

Saat ini, jaringan internasional telah menjadi dampak pola pikir manusia seperti media sosial, Google dan game on line. Hampir setiap orang memiliki media sosial seperti Facebook, Whats UpTwitter, Path, Instagram, Line, WeChat dan lain sebagainya. Media sosial membuat orang sibuk sendiri dalam akun mereka. Media sosial membuang waktu mereka dari jam ke jam sampai lupa waktu mereka. Game on line adalah salah satu penawaran yang paling menyenangkan bagi orangorang, terutama bagi pria karena para pemain game on-line berasal dari orang-orang yang berbeda di seluruh dunia. Google adalah situs web yang bagus yang disebut ilmu raja karena murid dapat mencari segala sesuatu di Google. Mereka pikir membaca itu tidak penting lagi. Semua pertanyaan dapat dijawab dengan bantuan Google. Jadi, jaringan internasional berdampak pada kesan membaca orang (Oke Zone.com, 2015 )

Dosen memiliki peran besar untuk menyukseskan pemahaman membaca siswa tetapi mengajar membaca itu tidaklah mudah. Ini terjadi dengan pengamatan penulis di Institut Kesehatan Deli Husada Deli Tua. Mahasiswa mengalami kesulitan dalam memahami bacaan dalam suatu teks. Metode dosen banyak yang tidak memuaskan mahasiswa. Mahasiswa tidak dapat menikmati cara mengajar dalam pemahaman membaca. Dosen meminta mereka untuk membaca teks setelah itu menjawab pertanyaan yang telah diberikan oleh mereka sebelumnya. Selain itu, dosen biasanya meminta siswa untuk mendapatkan ide utama dari informasi yang telah dibaca. Ini juga terjadi dengan pengalaman peneliti, ketika peneliti mengajar di Institut Kesehatan Deli Husada Fakultas Kesehatan Masyarakat Prodi Manajemen Informasi Kesehatan. Dosen harus menerapkan strategi yang sesuai untuk membantu mahasiswa dalam teks pemahaman mereka. (Bukit H, 2020).

Setelah menuangkan latar belakang yang ditemukan di lapangan, akhirnya peneliti menyadari betapa pentingnya membaca. Membaca benarbenar memberi efek besar bagi kehidupan manusia. Sebenarnya masalah pemahaman bacaan dapat diminimalkan dengan menggunakan strategi yang sesuai untuk mengajar membaca. Ada banyak strategi yang dapat digunakan untuk menyelesaikan masalah dalam membaca pemahaman seperti PQ4R (Pratinjau, Pertanyaan, Baca, Refleksi, Bacalah, dan Tinjauan), STAD (Divisi Prestasi Tim Siswa), Teknik Membaca Kritis, Teknik Membaca Kritis, Teknik Think-Pair-Share , RAP (Read, Ask, Paraphrase), dll. (Nunan, 2003: 750).

"Metakognisi dapat didefinisikan sebagai pemikiran tentang pemikiran kita" (Nunan, 2003: 750). Selain itu, Alexander (1977) mengatakan bahwa "Metakognisi adalah istilah yang digunakan untuk menjelaskan pengetahuan seseorang tentang fitur pemikirannya dan pengaturan dirinya". Strategi metakognisi dapat membuat mahasiswa menjadi kreatif atau meningkatkan kognitif mereka. Diyakini bahwa kekuatan metakognisi ini dapat menyelesaikan masalah pemahaman membaca.

Strategi metakognisi memiliki beberapa dasar yang dapat mendukung dalam tujuan pemahaman bacaan. Itu dapat menghubungkan pembaca ke informasi baru sebelum mulai membaca. Sebelum mahasiswa membaca teks mereka harus mengemukakan pendapat tentang apa yang mereka ketahui tentang topik tersebut. Mahasiswa menjadi sadar sebelum membaca teks. Dengan kata lain, tahapan strategi ini dibagi menjadi tiga tahap: sebelum, selama dan setelah membaca. Sebelum membaca, mahasiswa ditanya tentang apa yang mereka ketahui dan apa yang akan dipelajari. Selama membaca, 
dosen harus memantau kegiatan membaca mahasiswa. Yang terakhir adalah setelah membaca, mahasiswa dibagi kedalam kelompok, kemudian berdiskusi dengan teman-teman mereka dalam kelompok tentang teks. Brown et al (2009). Mahaiswa mengatur seluruh kegiatan mereka saat membaca. Dengan menerapkan strategi ini, peneliti mencoba untuk menyelidiki apakah strategi metakognisi mempengaruhi pemahaman membaca siswa atau tidak dalam teks deskriptif dengan mengamati skor siswa yang akan diperhitungkan hasilnya.(Bukit H, 2020)

Teks deskriptif terkait dengan menjelaskan seseorang, tempat, dan benda. Hal ini bermanfaat untuk dikuasai oleh mahasiswa karena mahasiswa di prodi Manajemen Informasi Kesehatan harus mempelajari teks deskriptif berdasarkan silabus dalam kurikulum departemen pendidikan di Indonesia berdasarkan Publikasi Pendidikan. Meninjau dari penjelasan diatas, masalah penelitian ini sebagai berikut: "Apakah strategi Metakognisi mempengaruhi pemahaman mahasiswa dalam membaca teks deskriptif?" Sehubungan dengan masalah tersebut, tujuannya adalah untuk mendapatkan jawaban apakah strategi Metakognisi mempengaruhi pemahaman membaca siswa dalam teks deskriptif yang sering dimunculkan dalam ujian TOEFL.

\section{METODE}

Desain penelitian ini adalah penelitian tentang pengaruh strategi metakognisi terhadap mahasiswa saat membaca teks deskriptif. Penelitian ini dilakukan berdasarkan desain kuantitatif eksperimental. Penelitian ini memiliki dua kelompok acak yaitu eksperimen group dan control group. Desain diterapkan untuk membandingkan data yang diambil dari kedua kelompok tersebut.

Populasi penelitian ini adalah mahasiswa Manajemen Informasi Kesehatan di Institut Kesehatan Deli Husada Deli Tua. Sampel diambil dari tingkat I, II dan III yang terdiri dari tingkat I: 29 mahasiswa, tingkat II : 30 mahasiswa, tingkat III : 17 mahasiswa. Jadi jumlah mahasiswa adalah 76 mahasiswa. Peneliti menggunakan random sampling. Arikunto (2009) mendefinisikan random sampling digunakan oleh peneliti jika populasi sampel adalah populasi homogen.

Teknik pengambilan sampel adalah dengan menggunakan simple random sampling. Sampel eksperimental dari tingkat I dan III yang terdiri dari 46 mahasiswa dan sampel kontrol kelompok tingkat II yang terdiri dari 30 mahasiswa. Peneliti menggunakan pertanyaan objektif (pilihan ganda) yang terdiri dari 25 item untuk mengukur pemahaman membaca mahasiswa. Teks deskriptif diperoleh dari empat teks dalam teks deskriptif dari teks ujian TOEFL. Setiap item tes terdiri dari lima pilihan, yaitu A, B, C, D, dan $E$. Pengaturan dan pembuatan instrumen diambil dari bahan-bahan tes TOEFL disesuaikan dengan silabus. Untuk menilai tes, ada 25 pertanyaan dalam empat teks. Peneliti memberikan empat poin dalam setiap jawaban yang benar. Jadi, jika siswa dapat menjawab 25 pertanyaan dengan benar, mereka mendapat skor 100 .

Tabel 1. Desain Penelitian

\begin{tabular}{cccc}
\hline Group & Pre-test & Variabel Independen & Post-test \\
\hline Percobaan & Y 1 & $\begin{array}{c}\text { Menggunakan Strategi } \\
\text { Metakognisi }\end{array}$ & Y2 \\
\hline Kontrol & Y 1 & $\begin{array}{c}\text { Tanpa Menggunakan } \\
\text { Strategi Metakognisi }\end{array}$ & Y2 \\
\hline
\end{tabular}




\section{HASIL DAN PEMBAHASAN}

Penelitian berdasarkan dilakukan desain kuantitatif eksperimental yang memiliki dua subjek acak. Sampel acak diambil dari Mahasiswa Manajemen Informasi Kesehatan tingkat 1 dan 3 sebagai kelompok eksperimen dan tingkat 2 sebagai kelompok kontrol. Dalam setiap kelompok diberikan pre-test dan posttest dalam tes yang sama tetapi kelompok eksperimen menerima perlakuan strategi Metakognisi dalam penelitian ini.

Kelompok kontrol tidak diberikan strategi Metakognisi dalam proses belajar mengajar. Para siswa diminta untuk membaca teks deskriptif setelah penulis membaca kalimat dengan kalimat dan kemudian mereka diminta untuk menemukan kata-kata yang sulit dan mencari arti kata-kata dari kamus mereka. Akhirnya, mereka menjawab pertanyaan dari teks. Sementara di kelompok eksperimen, para siswa diberikan strategi Metacognisi dalam membaca teks deskriptif. Mereka harus berpikir tentang apa yang akan mereka pelajari, apa yang mereka ketahui tentang teks dan berapa lama mereka selesai membaca teks dan kemudian mereka membaca teks secara individual. Mereka diminta menjawab pertanyaan yang diberikan oleh penulis setelah mereka selesai membaca teks. Mereka menjawab tentang mencari tahu pokokpokok teks, menulis kesulitan mereka selama membaca dan mengetahui apa yang harus mereka lakukan untuk meningkatkan pemahaman bacaan mereka.

Sebelum siswa diberikan perlakuan, peneliti memberikan 25 pertanyaan dalam pertanyaan pilihan ganda dengan 3 teks deskriptif yang diambil dari teks Ujian TOEFL untuk ketiga kelas. Setelah peneliti memberikan pengajaran, peneliti memberikan post-test untuk kelompok eksperimen. Juga diberikan kepada kelompok kontrol untuk mengetahui perbedaannya. Menguji hipotesis untuk mengetahui apakah hipotesis diterima atau ditolak.

Dalam penelitian ini, nilai t-tabel untuk derajat kebebasan (df) 58 pada tingkat signifikansi (a) 0,05 adalah 1,67. Sedangkan, t-mengamati yang diperoleh dari perhitungan rumus t-test untuk derajat kebebasan (df) 58 pada tingkat signifikansi (a) 0,05 adalah 4,1. Artinya t-mengobservasi lebih besar dari ttable, di mana 4,1>1,67. Kesimpulan dari data menunjukkan bahwa penggunaan strategi metakognisi mempengaruhi pemahaman membaca siswa dalam teks deskriptif.

Tabel 2. Hasil Analisis Terhadap Data Penelitian

\begin{tabular}{|c|c|c|c|c|c|c|c|c|}
\hline \multicolumn{9}{|c|}{ Paired Differences } \\
\hline & Mean & $\begin{array}{c}\text { Std } \\
\text { Deviati } \\
\text { on }\end{array}$ & $\begin{array}{l}\text { Std } \\
\text { Error } \\
\text { Mean }\end{array}$ & $\begin{array}{r}95 \% \text { C } \\
\text { Interv } \\
\text { Diffe }\end{array}$ & $\begin{array}{l}\text { idence } \\
\text { of the } \\
\text { nce }\end{array}$ & $\mathrm{t}$ & $\mathrm{df}$ & $\begin{array}{l}\text { Sig (2- } \\
\text { tailed) }\end{array}$ \\
\hline $\begin{array}{c}\text { Pretest- } \\
\text { Posttes } \\
t\end{array}$ & $-4,667$ & 5,857 & 1,069 & $-6,854$ & $-2,480$ & $-4,364$ & 29 & 000 \\
\hline
\end{tabular}

\section{Pembahasan}

Hasil penelitian ini dapat disimpulkan bahwa ada perbedaan antara rata-rata kelompok eksperimen dan kelompok kontrol. Perhitungan statistik menunjukkan bahwa t-diamati $(4,1)$ lebih tinggi dari t-tabel $(1,67)$ untuk tingkat kebebasan (df) 58 pada tingkat $a=0,05$ tingkat signifikansi. Ini membuktikan bahwa strategi Metakognisi berpengaruh signifikan terhadap pemahaman membaca mahasiswa dalam membaca teks deskriptif.

Dimana penelitian ini sejalan dengan penelitian yang telah dilakukan oleh Nainggolan, Bernard Richard 
dengan judul Pengaruh Strategi Metakognitif pada Pemahaman Membaca siswa di tahun 2013. Analisis dalam penelitiannya menunjukkan bahwa skor siswa dalam kelompok eksperimen lebih tinggi daripada skor siswa dalam kelompok kontrol. Pada tingkat signifikansi 0,05 derajat kebebasan (df) 82, t-diamati adalah 4,43 sedangkan t-tabel adalah 1,67. Kemudian, nilai-F adalah 1,01 dan Ftabel adalah 1,608 dengan derajat kebebasan (df) 82. Kesimpulannya adalah penggunaan strategi metakognitif memang mempengaruhi pada pemahaman membaca siswa.

\section{SIMPULAN DAN SARAN}

Berdasarkan analisis data, peneliti menyimpulkan bahwa terdapat pengaruh yang signifikan pada saat menggunakan strategi Metakognisi dalam mengajar untuk pemahaman membaca teks deskriptif. Mengajar siswa dengan menggunakan strategi Metakognisi lebih baik daripada tidak menggunakan strategi metakognisi.

Saran diberikan sebagai berikut:

1. Dosen Bahasa Inggris menerapkan strategi Metakognisi dalam mengajar teks pemahaman membaca kepada mahasiswa, terutama teks deskriptif karena terbukti ada pengaruh dalam menggunakan strategi Metakognisi dalam mengajar keterampilan pemahaman membaca.

2. Mahasiswa disarankan menggunakan strategi Metakognisi dalam meningkatkan pemahaman membaca mereka karena strategi Metakognisi dapat membantu mahasiswa lebih kreatif dalam belajar keterampilan membaca.

3. Peneliti lain yang tertarik untuk melakukan penelitian pemahaman membaca dengan genre lain untuk juga menggunakan strategi Metakognisi dalam melakukan penelitian.

\section{DAFTAR PUSTAKA}

Buku:

Alderson, J.C. 2000.Assessing Reading. United Kingdom: Camridge University.

Alexander, J. Estill. 1977. Teaching Reading Third Edition. United States: Scott Foresman Company.

Arikunto, S. 2010. Prosedure Penelitian. Jakarta: Rhineka Cipta.

Brown, H.D. 2001. Teaching by principles: and interactive approach to language pedagogy. New York: Longman.

Gerrot and Wignel. 2001. Making Sense of Functional Grammar. Cammeray, NSW: Antipodian Educational EuterPrises.

Grabe, W and Stoller, Fredricka. L. 2002. Teaching and Researching Reading. Malaysia: Pearsoned.

Hacker, Dunlosky andGraesser. 2009. Handbook of Metacogniton in Education. New York: Routledge.

Nunan, David. 1999. Second Language Teaching \& learning. Canada: Heinle.

\section{Jurnal:}

Shannon, S.V. 2008. "Using Metacognitive Strategies and Learning Styles to Create SelfDirected Learners: Institute for Learning Styles Journal," Target 14-27.

\section{Artikel online:}

Blakey, E., and Spence, S. 1990. Developing Metacognition. New York: ERIC Digest. (ERIC NO.: ED327218). Retrieved December 1999, from http://www.edpsycinteractive.org/f 
iles/metacogn.html. Accessed in March 2015.

Oke Zone (online). 2014. Minat Baca Indonesia Satu Banding Seribu. diakses:

http://news.okezone.com/read/20 14/09/09/373/1036695/minatbaca-indonesia-satu-bandingseribu.

Tribun News (online). 2014. Minat Baca Masyarakat Masih Rendah. http://wartakota.tribunnews.com/ 2014/01/21/minat-bacamasyarakat-masih-rendah?page $=1$ 